\title{
Çocuklarda kompartman sendromu
}

\author{
Compartment syndrome in children
}

\author{
Mithat Öner, Yiğit Umur Cırdı
}

Erciyes Üniversitesi Tıp Fakültesi, Ortopedi ve Travmatoloji Kliniği, Kayseri

\begin{abstract}
Kompartman sendromu, ortopedik açıdan acil olan ender durumlardan biridir. Artmış kompartman içi basınç doku perfüzyonunun bozulmasına yol açar. Dolayısıyla, bu durumun devam etmesi halinde geri dönüşümsüz doku hasarı kaçınılmazdır. Geç teşhis veya müdahalede ihmal, kalıcı nöromusküler hasar ve hattâ uzuv kaybı gibi çok kötü sonuçlara neden olabilir. Çocuklarda kompartman sendromunun klinik bulgularının tespiti kolay olmayabilir. Bu nedenle hekimlerin çocuklarda gelişebilecek olan kompartman sendromunun tanısı ve acil tedavi algoritması hakkında bilgi sahibi olmaları gerekir. Ortopedik cerrah, kompartman sendromu gelişmesine yol açan risk faktörlerini ve bu açıdan yüksek risk taşıyan kırıkları ve durumları bilmelidir. Kompartman sendromu tanısı konduktan sonra, tedavisi acil fasyotomi ile kompartman basıncının düşürülerek dolaşımın ve doku perfüzyonunun yeniden sağlanmasıdır. Bu nedenle, tanı ve tedavi sürecinde zaman kritik rol oynar. Bu yazının amacı, kompartman sendromu gelişme ihtimali yüksek olan bireyler hakkında cerrahların bilgilendirilmeleri ve günlük pratikte karşımıza çıkabilecek durumlar hakkında bilinçlendirilmeleridir. Komplikasyonlarını önlemenin en iyi yolu kompartman sendromu şüphesini her daim ayırıcı tanıda bulundurmak ve erken müdahalede bulunmaktır.
\end{abstract}

Anahtar sözcükler: kompartman sendromu; çocukluk çağı
Compartment syndrome is one of the few orthopedic emergencies. Increased intra-compartmental pressure result in decreased tissue perfusion. Therefore, irreversible tissue damage is inevitable if this situation persists. Delayed diagnosis or neglected treatment may lead to catastrophic results such as; permanent neuromuscular damage and even loss of affected extremity. Diagnosis can be particularly difficult in children. Thus, physicians must be aware of the findings of compartment syndrome in children and be capable of managing the emergency treatment. Risk factors and high-risk cases in terms of compartment syndrome have to be well-known by any physician. If the diagnosis of compartment syndrome is settled, emergent fasciotomy and decompression is indicated to restore tissue perfusion. Therefore, timing is crucial in the treatment and diagnosis of compartment syndrome. The aim of this article is to inform surgeons about individuals with high probability of developing compartment syndrome and to raise awareness about situations that may occur in daily practice. It must be keep in mind that the best way to avoid complications is to keep the high suspicion up for possible compartment syndrome and take immediate action.

Key words: compartment syndrome; childhood

sonuç osteo-fasyal kompartmana hızlı bir şekilde sıvı birikimi sonucu kompartman içi basıncının artmasıdır. Bu basınç artışı eşik seviyeyi aştıktan sonra mikrovasküler dolaşım yetersizliği gelişmeye başlar. Doku perfüzyonunun azalmasına bağlı olarak, kas ve sinir dokuda iskemi gelişir. Bu durum devam ettiği sürece ise, uzun vadede geri dönüşümsüz değişiklikler ortaya çıkar ve nekroz ile sonuçlanır. Bu süreç geri döndürülemediği takdirde, olayın ciddi fonksiyon kaybı ve hatta ekstermite kaybına kadar gidebileceği akılda tutulmalıdır.

- İletişim adresi: Prof. Dr. Mithat Öner, Erciyes Üniversitesi Tıp Fakültesi Ortopedi ve Travmatoloji Kliniği, Gevher Nesibe Hastanesi, 3. kat, Talas Yolu 5. km, Melikgazi, Kayseri Tel: 0538 - 8714636 e-posta: drmithatoner@gmail.com

- Geliș tarihi: 2 Șubat 2019 Kabul tarihi: 2 Șubat 2019 
Kompartman sendromunun etiyolojisi çok çeşitli tanımlanmış olsa da, anahtar özellik klinik şüphedir. Çocuklarda kompartman sendromu çoğunlukla kırıklar ile birlikte gözlenir; ancak kırık olsa da olmasa da, kompartman sendromu açısından yüksek risk teşkil eden olgular yakından takip edilmelidir. Şu unutulmamalıdır ki, kompartman sendromu klinik bir tanıdır. Erken dönemde ağrı, uyuşma ve şişlik gibi kompartman sendromu semptomları bilinse de, çocuk hastanın ağrıyı tam olarak betimleyemeyeceği, uyuşmayı tarif edemeyeceği ve çoğu durumda ajitasyona bağ lı sağlıklı veri elde edilemeyeceği göz önünde tutularak, klinik gidişatın yakından izlenmesi son derece önemlidir. ${ }^{[1,2]}$

Kompartman sendromunun tedavisindeki amaç, acil bir şekilde doku perfüzyonunun yeniden sağlanmasıdır. Yapılan bir çalışmada, ortopedik genel malpraktis olgularının \%75'inin hekim lehine sonuçlandığı, ancak kompartman sendromu içeren durumlarda bu oranın ancak \%45 olduğu gösterilmiştir. ${ }^{[3]}$ Bu nedenle, tanının erken konulması, mümkün olan en fazla dokunun kurtarılması açısından son derece önemlidir.

\section{PATOFIZYOLOJi}

Patolojiye neden olan mekanizma açıklanabilse de, halen bu konuda bir fikir birliği sağlanamamıştır ve tartışmalı konular mevcuttur. Bu konuda şu an için üç ana teori sayabiliriz. ${ }^{[1]}$ Bunlar;

1) venöz dolaşımın bozulması,

2) arteriyel akımın tıkanması ve

3) arter duvarı spazmına bağlı olarak, arteriyel akımın engellenmesidir.

Son zamanlarda hayvan modelleri üzerinde yapılan çalışmalarda, kompartman sendromuna neden olan mekanizmanın daha çok kompartman içi basıncın artmasına bağlı olarak venöz sistemin kompresyonu olduğu düşünülmektedir. ${ }^{[4,5]}$

Doku beslenmesi, kapiller perfüzyon basıncı ile interstisiyel sıvı basıncı arası farka bağlıdır. Kompartmanı saran fasya, elastik olmayan avasküler bir yapıdadır; bu nedenle, akut gelişen genişlemeye karşı dirençlidir. ${ }^{[5]}$ Dolayısıyla, artan kompartman basıncına bağlı olarak venöz basınç da yükselir. Venöz basıncın yükselmesi, interstisiyel basıncın artmasına ve dolaylı olarak perfüzyonun azalmasına neden olur. Lenfatik boşalımın ve venöz dönüşün azalması sonucu, ödem daha da artar ve bu "pozitif geribildirim" (positive feed-back) mekanizması, sürekli kendini tekrar eden patofizyolojik bir döngüdür. Bu döngüyü kırmanın tek yolu, kompartmanın genişletilerek doku perfüzyonunun yeniden sağlanmasıdır. ${ }^{[6,7]}$
İskemiye en duyarlı doku sinir dokusudur. Hipoestezi ve parestezi şikâyetleri, iskemi yerleşmeye başladıktan sonraki ilk 30 dakika içinde görülür. Ancak, geri dönüşümsüz fonksiyon kaybı için iskeminin 12-24 saat devamlılık göstermesi gerekir. Kas dokuları ise iskemiye daha dayanıklıdır; bunlar iskemi sonrası fonksiyonlarını 2-4 saat kadar korur, ancak 4. saatten itibaren geri dönüşümsüz hasar başlar. Burada önemli olan nokta, geri dönüşümsüz durum klinik olarak beklenmeden, kompartmanın bir an önce gevşetilmesi gerekliliğidir. ${ }^{[1]}$

\section{TANI}

Kompartman sendromunun kesin tanısında, basınç için farklı eşik değerleri bildirilmekte ve kesinleşmiş bir değer henüz bulunmamaktadır. Burada önemli olan nokta, bu değerlerin hem çocuklar için geçerliliğinin tartışmalı olması hem de çocuklarda kompartman içi basınç ölçümünün son derece zor olmasıdır. Kompartman sendromu denilince, rutin olarak akla 5P bulgusu -Pain (ağrı), Pallor (soluk ten rengi), Paresthesia (uyuşma hissi), Pulselessness (zayıf nabız), Paralysis (harekette güçsüzlük)- gelir. Bu bulguların çocuk hasta grubunda saptanması son derece zordur. Ajite durumdaki bir çocuk hastadan tanısal cevaplar alabilmek pek olası değildir. Ayrıca, yapılan bir çalışmada, kırık olmamasına rağmen kompartman sendromu gelişen 39 hastadan sadece birinde $(\% 0,02) 5 \mathrm{P}$ bulgusunun beşinin de mevcut olduğu görülmüştür. ${ }^{[8]}$ Aynı problem bir başka çalışma için hipotez oluşturmuştur. Bae ve ark., 5P bulgusunun çocuklarda geçerli olmadığını bildirmişlerdir. Bunun yerine, artan analjezik ihtiyacının kompartman sendromu açısından daha yol gösterici olduğunu göstermişlerdir. Bu nedenle bu yayın, klasik 5P bulgusu yerine 3A -artan Analjezik ihtiya$\mathrm{Cl}$, Anksiyete, Ajitasyon- bulgusunun daha belirleyici olduğunu göstermektedir (Tablo 1). ${ }^{[9]}$ Bir başka

Tablo 1. Kompartman sendromunun $5 \mathrm{P}$ ve $3 \mathrm{~A}$ tanısal bulguları ${ }^{[9]}$

\begin{tabular}{ll}
\hline $\mathbf{5 P}$ & 3A \\
\hline Pain (ağrı) & Analjezik ihtiyacı (artmış) \\
Pallor (soluk ten rengi) & Anksiyete \\
Paresthesia (uyuşma hissi) & Ajitasyon \\
Pulselessness (zayıf nabız) & \\
Paralysis (harekette güçsüzlük) &
\end{tabular}


çalışma ise 5P bulgusundan üçünün olmasının kompartman sendromu açısından \%90 gibi yüksek bir olasılık gösterdiğini bildirmektedir. ${ }^{[10]}$

\section{ETIYOLOji}

Kompartman sendromu çoğunlukla yüksek enerjili travma sonrası düşünülür. Bunun yanında, yanıklar, penetran travma, sirküler alçı, sıkı bandajlama, enfeksiyon, kanama bozuklukları, damar yolundan sıvı kaçağı ve arter yaralanması gibi birçok nedene bağlı olabileceği unutulmamalıdır. Özellikle çoklu travma hastalarında rahatlıkla gözden kaçabileceği dikkate alınmalıdır. ${ }^{[1,11]}$

Bazı özel hasta gruplarında, kompartman sendromu klinisyenin ön tanısında mutlak suretle yer almalıdır. Yenidoğanlarda geçirilmiş doğum travmaları, traksiyonel yaralanma bulguları, karaciğer hastalıklarına sekonder koagülopatisi olan olgular, böcek ve yılan sokmaları gibi örneklerde nadiren karşılaşılsa da, tanının atlanması sonucu ekstremite kaybı olasıdır. ${ }^{[1]}$ Bunların haricinde, üst ve alt ekstremite için travmatik etiyolojik nedenler aşağıda sıralanmıştır.

\section{Suprakondiler Humerus Kırıkları}

Bu kırıklar, çocuklarda tüm kırıkların yaklaşık \%3'ünü oluşturur. Komplikasyon olarak kompartman sendromu gelişme oranı 1000'de 1-3'tür. ${ }^{[12,13]}$ En çok etkilenen bölge ise volar yüzün derin kompartmanıdır. Yapılan çalışmalarda kapalı redüksiyon sonrası dirseğin $90^{\circ}$ 'den fazla fleksiyonda olmasının kompartman sendromu gelişmesi için risk oluşturduğu gösterilmiştir. ${ }^{[13,14]}$ On yıllık çok merkezli bir çalışmada ${ }^{[15]}$, düşü̈k enerjili travma sonrası suprakondiller humerus kırı̆̆ı olan ve radyal nabızı alınan hastalar incelenmiş ve toplam 11 kompartman sendromu ile karşılaşılmıştır. Bu 11 hastanın 10'unda başvuru esnasında ileri derecede şişlik olduğu ve cerrahi işlemi bekleme sürelerinin ortalama 22 saat olduğu bulunmuştur. Bu çalışma ile birlikte son yayınlar, ileri derecede şişliği ve ağrı hissinin azalmasından dolayı nörolojik defisiti olan çocuklarda tedavinin ertelenmemesini önermektedir. ${ }^{[1,15]}$

\section{Humerus Distal ve Önkol Çift (Yüzen Dirsek) Kırıkları}

Bu iki kırı̆ı̆n birlikteliği, kompartman sendromu açısından yüksek risk oluşturur. ${ }^{[12,16]} \mathrm{Bu}$ nedenle bu tip kırıklarda, mümkünse kapalı redüksiyonun tercih edilmesi ve sirküler alçılama yapmayarak iyatrojenik risk faktörlerinden kaçınılması gerekir. Muchow ve ark.'nın yaptığı, yüzen dirsekleri içeren geniş bir çalışmada $(n=150)$ kompartman sendromu gözlenmemiş, ancak nörolojik defisit riskinin suprakondiller kırıklara oranla iki kat fazla olduğu belirtilmiştir. ${ }^{[17]}$ Yine de, klinik tecrübemizden ve literatürden yola çıkarak, yüzen dirseğin kompartman sendromu açısından anlamlı ve kuvetli bir risk faktörü olduğu hipotezini desteklemekteyiz. ${ }^{[12,16]}$

\section{Önkol Kırıkları}

Anatomik komşuluktan ötürü, önkol kırıkları sonrası kompartman sendromu takibi titizlikle yapılmalıdır (Şekil 1). Median sinir, anterior interosseöz sinir (AIN) ve ulnar sinir volar kompartman içerisinde seyretmektedir. Median sinir daha derinde seyrettiğinden dolayı kompartman sendromundan en çok etkilenen yapıdır. Özellikle Volkman kontraktürü sonrasında median sinir üzerinde skar dokusu gelişebilmektedir. ${ }^{[18]}$ iki yüz seksen beş önkol çift kırığının incelendiği bir çalışmada, 205 kırık kapalı redüksiyon ile tedavi edilmiş ve bu grupta kompartman sendromuna rastlanmamıştır. Seksen kırık ise intramedüller elastik çivi ile tespit edilmiş ve bu hastalardan altısında kompartman sendromu gelişmiştir $(\% 7,5) \cdot{ }^{[19]} \mathrm{Bu}$ veriler ışığında, özellikle çocuklarda intramedüller elastik çivi kullanımın, operasyon esnasında zorlayıcı manipülasyonun ve uzun cerrahi süresinin kompartman sendromu açısından risk faktörü olduğu ve cerrahi planlamanın bu faktörler göz önünde bulundurularak yapılması gerektiğinin altı çizilmektedir. Buna karşın bir diğer çalışma ise, intramedüller elastik çivi tespitini kırık olduktan 24 saat sonra yapmanın riski azalttığını ve elastik çivinin ilk 24 saatte konulmasının kompartman sendromu için risk faktörü olduğunu öne sürmüştür. ${ }^{[20]}$ Kapalı redüksiyon için zorlayıcı manipülasyon uygulamaktansa, küçük bir insizyon ile cerrahi sürenin kısaltılabileceği unutulmamalıdır. Yukarıda bahsedilen risk faktörleri göz önünde bulundurulduğunda, elastik çivi öncesi uzun süreli zorlayıcı manipülasyon kesinlikle önerilmemektedir. ${ }^{[1,21]}$

\section{Alt Ekstremite Kırıkları}

Alt ekstremite kırıkları, çoğunlukla yüksek enerjili travmalara ikincil gelişir. Çocuklarda kompartman sendromu, genelde tibia bölgesinde görülür. Femur kırıkları sonrasında gelişen kompartman sendromu son derece nadirdir. Literatürde, femur kırı̆̆ı sonrası kompartman sendromu gelişimi çoğunlukla iyatrojenik nedenlidir; femur kırığı sonrası 90/90 spika alçısı sonrası gelişen kompartman sendromu olgusu mevcuttur; ancak, kompartman sendromu kırık komplikasyonu olarak değil hatalı alçılama tekniğinden dolayı gözlenmiştir. $^{[22]}$ Bir diğer olguda, üç yaşında bilateral femur kırığı olan hastaya cilt traksiyonu uygulanması sonucu kompartman sendromu gelişmiştir. ${ }^{[23]}$ Burada önemli olan 


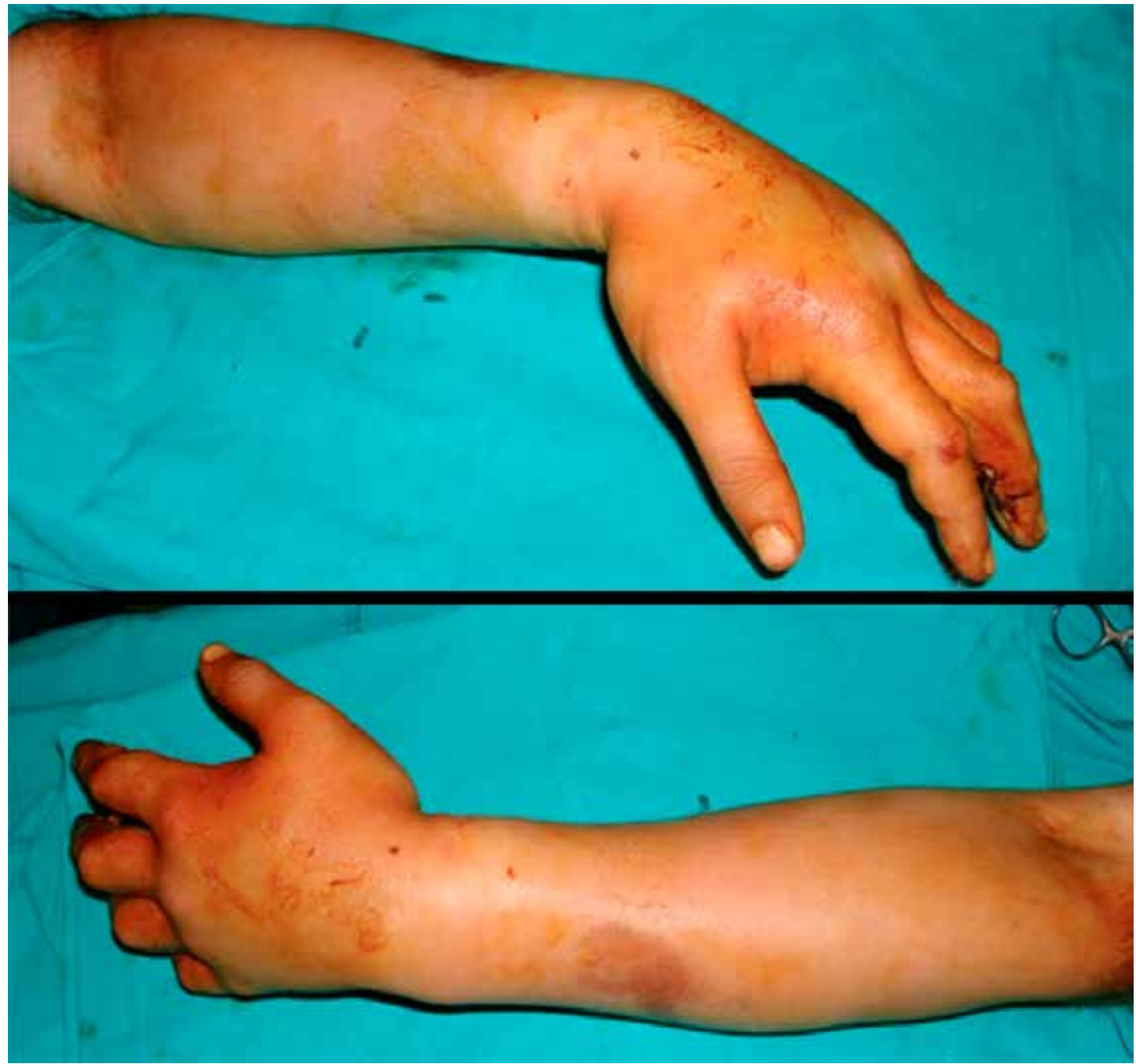

Şekil 1. Sekiz yaşında önkol çift kemik kırıklı erkek olguda kompartman sendromu.

nokta, proksimal femur bölgesinde artmış kompartman basıncını kompanse edecek hacim mevcuttur; bu nedenle, iyatrojenik risk faktörlerinden kaçınılmalıdır.

Çocuklarda en sık karşılaşılan klinik senaryo, akut travmaya sekonder bacakta gelişen kompartman sendromudur. Çocuklarda normal bacak kompartman basıncı, yetişkinlere göre daha yüksektir. Manometre ile ölçüm yapılırken bu fark, endikasyon belirlemesi açısından göz önünde bulundurulmalıdır. Daha önce de bahsedildiği gibi, özellikle beş yaş altı çocuklarda, semptomların kelimelerle ifade edilmesi süreci zorlu olabilir ve klinik şüphe halinde acil fasyatomi planlanmalıdır. Burada vurgulamak istediğimiz nokta şudur: Zamanında ve doğru endikasyon ardından fasyatomi ile tedavi edilen olguların uzun dönem sonuçları çoğunlukla mükemmeldir ve kompartman sendromu geliştikten 72 saat sonra olsa dahi, fasyatomi açılması uzun dönem sonuçlarını olumlu şekilde etkiler (kalıcı ağrı, fonksiyon kaybı ve duyu kaybı bakımından).[24]

Tibia kırı̆gı olan olgular, kompartman sendromu açısından mutlaka yakın takip gerektirir. Tibia kırıkları sonrası \%4-11,6 gibi yüksek bir oranda kompartman sendromu görülebilir. ${ }^{[2,26]}$ Özellikle, yüksek enerjili ve direkt travmalar kompartman sendromu açısından risk oluşturur.

\section{SONUÇ}

Çocuklarda kompartman sendromunun klinik tanısı her zaman kolay olmayabilir. Rutin muayene bulgularının çocuk hasta grubunda farklılık gösterebileceği 

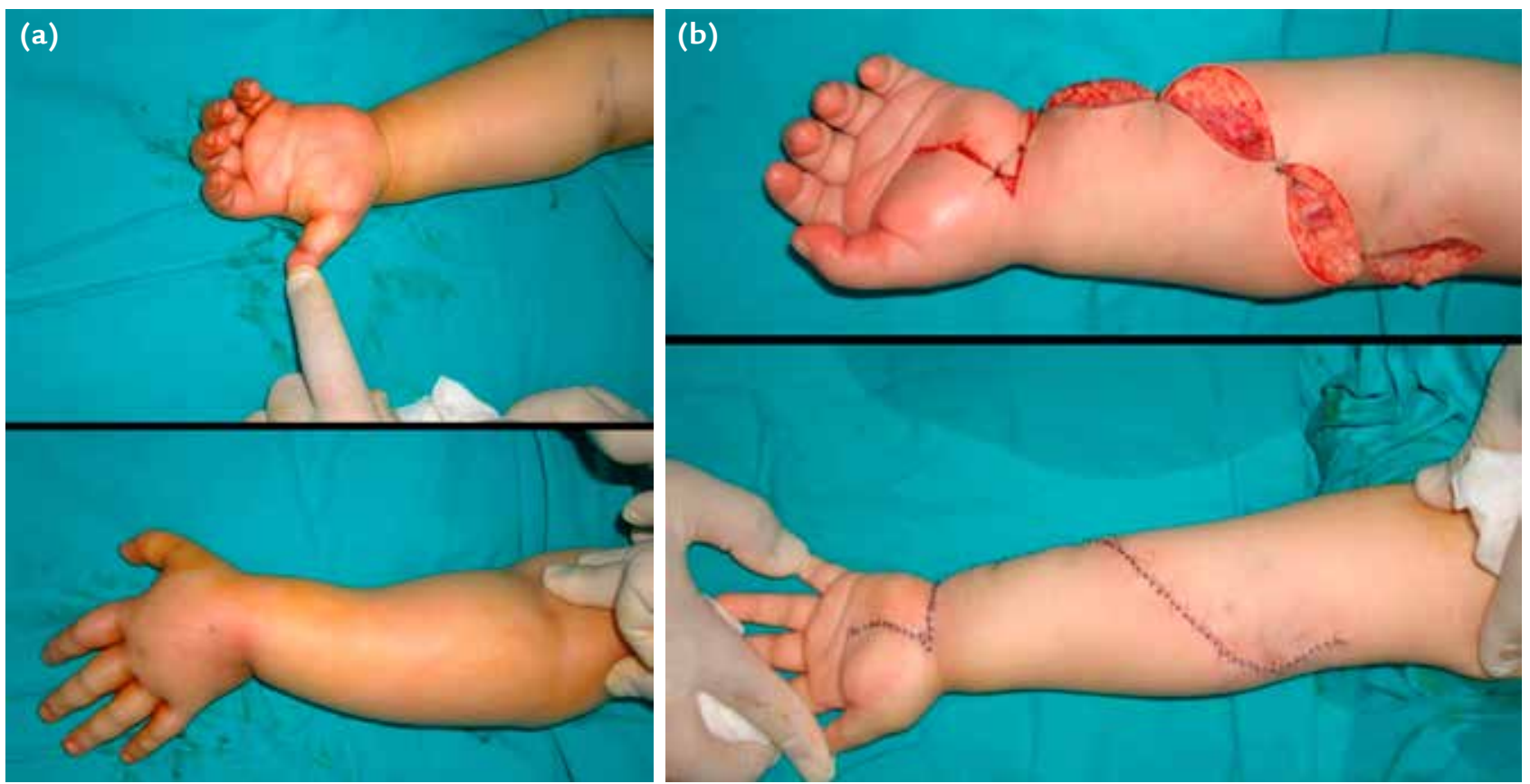

Şekil 2. a, b. Üç yaşındaki, suprakondiller humerus kırıklı kız olguda kompartman sendromu (a). Erken fasyotomi ve kapatılması sonrası (b).

unutulmamalıdır. Risk faktörü olan olgularda kompartman içi basıncı arttırabilecek sirküler traksiyon, sargı ve sirküler alçı, hızlı şekilde gevşetilmeli ve açılmalıdır. Mutlak tedavi acil fasyatomidir ve bu işlemin geri dönüşümsüz doku hasarı yerleşmeden önce yapılması kritiktir (Şekil 2). Üst ekstremitede; volar insizyon ile, yüzeyel ve derin kompartman ile, gerektiğinde karpal tünel serbestleştirilmelidir. Alt ekstremitede ise; cerrahın tercihine bağlı olarak tek veya çift insizyon ile dört kompartmanda da basınç azalması hızla sağlanmalıdır. Doğru teşhis ve zamanında tedavi ile başarılı sonuçlar elde edilir.

\section{KAYNAKLAR}

1. Hosseinzadeh $P$, Hayes $C B$. Compartment Syndrome in Children. Orthop Clin North Am 2016;47(3):579-87. Crossref

2. Prasarn ML, Ouellette EA, Livingstone A, Giuffrida AY. Acute pediatric upper extremity compartment syndrome in the absence of fracture. J Pediatr Orthop 2009;29(3):263-8. Crossref

3. Bhattacharyya T, Vrahas MS. The medical-legal aspects of compartment syndrome. J Bone Joint Surg Am 2004;86$A(4): 864-8$. Crossref

4. Vollmar B, Westermann S, Menger MD. Microvascular response to compartment syndrome-like external pressure elevation: an in vivo fluorescence microscopic study in the hamster striated muscle. J Trauma 1999;46(1):91-6. Crossref
5. Fry WR, Wade MD, Smith RS, Asensio-Gonzales JA. Extremity compartment syndrome and fasciotomy: a literature review. Eur J Trauma Emerg Surg 2013;39(6):561-7. Crossref

6. Friedrich JB, Shin AY. Management of Forearm Compartment Syndrome. Hand Clin 2007;23(2):245-54. Crossref

7. Kistler JM, Ilyas AM, Thoder JJ. Forearm Compartment Syndrome: Evaluation and Management. Hand Clin 2018;34(1):53-60. Crossref

8. Livingston $\mathrm{K}$, Glotzbecker $\mathrm{M}$, Miller PE, Hresko MT, Hedequist D, Shore BJ. Pediatric Nonfracture Acute Compartment Syndrome: A Review of 39 Cases. J Pediatr Orthop 2016;36(7):685-90. Crossref

9. Bae DS, Kadiyala RK, Waters PM. Acute compartment syndrome in children: contemporary diagnosis, treatment, and outcome. J Pediatr Orthop 2001;21(5):680-8. Crossref

10. Noonan KJ, McCarthy JJ. Compartment syndromes in the pediatric patient. J Pediatr Orthop 2010;30:S96-101. Crossref

11. McQueen M, Duckworth A. The diagnosis of acute compartment syndrome: a review. Eur J Trauma Emerg Surg 2014;40(5):521-8. Crossref

12. Blakemore LC, Cooperman DR, Thompson GH, Wathey C, Ballock RT. Compartment syndrome in ipsilateral humerus and forearm fractures in children. Clin Orthop Relat Res 2000;376:32-8. Crossref

13. Battaglia TC, Armstrong DG, Schwend RM. Factors affecting forearm compartment pressures in children with supracondylar fractures of the humerus. J Pediatr Orthop 2002;22(4):431-9. Crossref

14. Mubarak SJ, Carroll NC. Volkmann's contracture in children: Aetiology and prevention. J Bone Joint Surg Br 1979;61$B(3): 285-93$. Crossref 
15. Ramachandran M, Skaggs DL, Crawford HA, Eastwood DM, Lalonde FD, Vitale MG, Do TT, Kay RM. Delaying treatment of supracondylar fractures in children: has the pendulum swung too far? J Bone Joint Surg Br 2008;90-B(9):1228-33. Crossref

16. Robertson AK, Snow E, Browne TS, Brownell ST, Inneh I, Hill JF. Who Gets Compartment Syndrome?: A Retrospective Analysis of the National and Local Incidence of Compartment Syndrome in Patients With Supracondylar Humerus Fractures. J Pediatr Orthop 2018;38(5):e252-6. Crossref

17. Muchow RD, Riccio Al, Garg S, Ho CA, Wimberly RL. Neurological and Vascular Injury Associated With Supracondylar Humerus Fractures and Ipsilateral Forearm Fractures in Children. J Pediatr Orthop 2015;35(2):121-5. Crossref

18. Friedrich JB, Shin AY. Management of forearm compartment syndrome. Hand Clin 2007;23(2):245-54. Crossref

19. Yuan PS, Pring ME, Gaynor TP, Mubarak SJ, Newton PO. Compartment syndrome following intramedullary fixation of pediatric forearm fractures. J Pediatr Orthop 2004;24(4):3705. Crossref

20. Flynn JM, Jones KJ, Garner MR, Goebel J. Eleven years' experience in the operative management of pediatric forearm fractures. J Pediatr Orthop 2010;30(4):313-9. Crossref
21. Blackman AJ, Wall LB, Keeler KA, Schoenecker PL, Luhmann SJ, O'Donnell JC, Gordon JE. Acute compartment syndrome after intramedullary nailing of isolated radius and ulna fractures in children. J Pediatr Orthop 2014;34(1):50-4. Crossref

22. Mubarak SJ, Frick S, Sink E, Rathjen K, Noonan KJ. Volkmann contracture and compartment syndromes after femur fractures in children treated with 90/90 spica casts. J Pediatr Orthop 2006;26(5):567-72. Crossref

23. Janzing $H$, Broos $P$, Rommens $P$. Compartment syndrome as a complication of skin traction in children with femoral fractures. J Trauma 1996;41(1):156-8. Crossref

24. Flynn JM, Bashyal RK, McKeever MY, Garner MR, Launay F, Sponseller PD. Acute traumatic compartment syndrome of the leg in children: diagnosis and outcome. J Bone Joint Surg Am 2011;93(10):937-41. Crossref

25. Hope PG, Cole WG. Open fractures of the tibia in children. J Bone Joint Surg Br 1992;74-B(4):546-53. Crossref

26. Shore BJ, Glotzbecker MP, Zurakowski D, Gelbard E, Hedequist DJ, Matheney TH. Acute compartment syndrome in children and teenagers with tibial shaft fractures: incidence and multivariable risk factors. J Orthop Trauma 2013;27(11):616-21. Crossref 